\title{
Immunonutritional support as an important part of multidisciplinary anti-cancer therapy
}

\author{
KAROLINA KAŹMIERCZAK-SIEDLECKA ${ }^{1}$, AGNIESZKA DACA², MARCIN FOLWARSKI ${ }^{3}$, \\ WOJCIECH MAKAREWICZI, ANNA LEBIEDZINSSKA ${ }^{4}$
}

${ }^{1}$ Department of Surgical Oncology, Medical University of Gdansk, Gdansk, Poland

${ }^{2}$ Department of Pathology and Experimental Rheumatology, Medical University of Gdansk, Gdansk, Poland

${ }^{3}$ Department of Clinical Nutrition and Dietetics, Medical University of Gdansk, Gdansk, Poland

${ }^{4}$ Department of Dietetics, Pope John Paul II State of Higher Education in Biala Podlaska, Poland

\begin{abstract}
Immunonutrition is one of the most important parts of nutritional treatment in patients with cancer. There are studies which confirm positive effects of using immunonutrition (arginine, glutamine, omega-3 fatty acids, nucleotides, pre-and probiotics) among others on the reduction of the pro-inflammatory cytokines concentrations, shortening of the hospital stay and improvement of the nutritional status. Arginine takes part not only in wound healing process, but also it improves body's immunity and reduces the incidence of infections. Glutamine reduces the incidence of acute grade 2 and 3 esophagitis and improves quality of life of gastric cancer patients. Omega 3-fatty acids have the ability to inhibit the activity of $\mathrm{NF}-\kappa \mathrm{B}$. They also reduce the symptoms of graft-versus-host disease in patients undergoing hematopoietic cell transplantation. Nucleotides support the regeneration of intestinal villi. Probiotics play many roles, mainly inhibit the process of carcinogenesis, reduce the incidence of diarrhea and modify intestinal microbiome. However, there are studies indicating the lack of advantages of using immunonutrition compared to standard nutrition. Currently, there is no clear evidence for the use of formulae enriched with immunonutrients versus standard oral nutritional supplements exclusively in the preoperative period. This review summarizes the current knowledge about the role of immunonutrition in supporting treatment of cancer diseases.
\end{abstract}

Key words: cancer, probiotics, glutamine, omega-3 fatty acids, Immunonutrition, arginine, nucleotides.

(Centr Eur J Immunol 2020; 45 (4): 454-460)

\section{Introduction}

Multidisciplinary anti-cancer therapy includes: pharmacological and surgical treatment, radiotherapy and nutritional support. The types of nutritional treatment are oral nutrition with oral nutritional supplements (ONS), enteral and parenteral nutrition [1]. Recently, special interest is directed towards nutritional immunomodulatory substances, called immunonutrition [2, 3]. The purpose of using these substances is to gain a beneficial effect on the immune system and, consequently, improve the effects of nutritional treatment. The role of immunonutrition mainly involves the supplementation of essential substances that are responsible for the immune system functioning, the control of inflammation and the reduction of the potential risk and effect of SIRS (systemic inflammatory reaction syndrome) in the course of malignancy $[1,2]$. According to the European Society for Clinical Nutrition and Metabolism (ESPEN), people with medium and high risk of developing malnutrition (in particular, patients with planned surgery within the upper gastrointestinal tract), should have immunonutrition introduced (e.g. arginine, omega-3 fatty acids and nucleotides) in the perioperative period by the oral / enteral way [4]. The Polish guidelines emphasize the need to use such a mixture (regardless of the patient's nutritional status) in people undergoing extensive surgery due to neck cancer (laryngectomy, pharyngectomy) and in the case of esophagectomy, gastric and pancreatoduodenectomy [5]. Immunomodulatory components applicable to patients with cancer are presented on the Figure 1 [2, 3].

\section{Arginine}

Arginine, one of the basic amino acids, is a substrate for the synthesis of many cellular proteins, ornithine, nitric oxide, polyamines, proline, glutamic acid, glutamine and creatine [6]. It is essential for normal growth and development of children. Its' endogenous synthesis is sufficient for proper development, growing and functioning as long as 


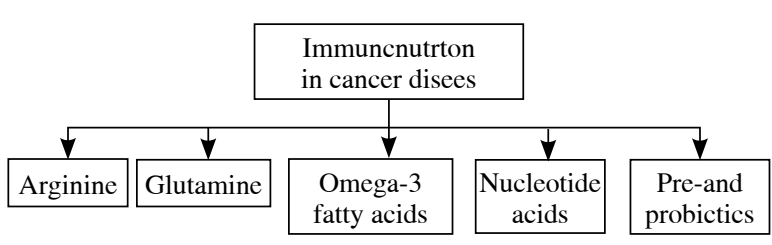

Fig. 1. Immunomodulatory components used as an immunonutrition in cancer diseases. Own elaboration based on literature $[2,3]$

it happens under the physiological conditions both in children and adults. Some clinical conditions, especially those with predominant catabolism, including burns and cancer cachexia, characterize higher demand for this amino acid $[2,6]$. The endogenous synthesis of arginine takes place mainly in kidneys and enterocytes. However, the main source of arginine for the human body is diet [6]. The plant proteins are especially rich in this amino acid [7].

Arginine takes part in many processes. Amongst them, the participation in the NO (nitric oxide) production seems really important. In vascular endothelium cells, in the presence of NOS (nitric oxide synthase), arginine takes part in the synthesis of nitric oxide (NO) as its sole and unique substrate. This mechanism is presented on Figure 2 [7, 8].

That in itself raised many questions about safety of arginine supplementation in severely ill patients, especially those at risk of sepsis development. But what is important about NO features, is its role not only in sepsis development, but also in arterial vasodilatation, bacterial clearance and immune system cells activation (among them e.g. macrophages, neutrophils, T cells) [9]. That affects various organs microperfusion, oxygen delivery and wound healing [10].

Some scientific data suggest, that arginine is critical for tumor cells development and proliferation, which also posed many questions regarding the wisdom of arginine supplementation in cancer states $[6,11]$. Nowadays, especially due to evident proofs that arginine or its' metabolites influence the thymic production of T cells, functioning of NK cells, granulocytic phagocytosis and in general anti-tumor cytotoxicity $[6,12,13]$, the role of arginine in immunonutrition seems to be well established, proved by many clinical trials and meta-analysis [14].

Arginine is the source of ornithine for the synthesis of proline, which is essential for the proper synthesis of collagen. The activity of arginine in macrophages at the tissue damage parts indicates its' participation in the wound healing process [7]. In an animal model $(n=18)$ it was shown that a mixture containing arginine $(200 \mathrm{mg} / \mathrm{kg}$ body mass $)$, glutamine $(200 \mathrm{mg} / \mathrm{kg})$ and $\beta$-hydroxy- $\beta$-methylbutyrate $(40 \mathrm{mg} / \mathrm{kg})$ reduces inflammation and positively affects wound healing [15].

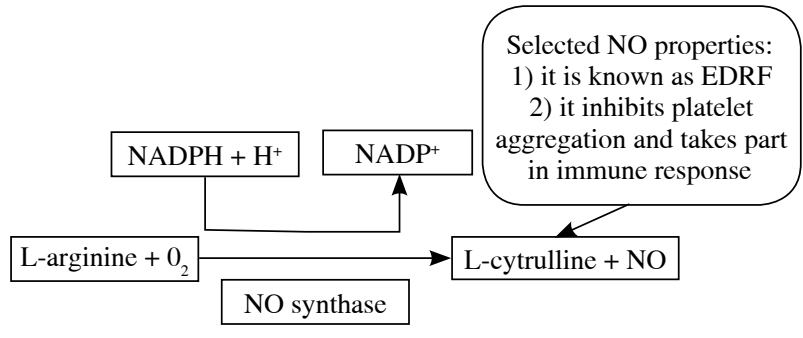

EDRF - endothelium-derived relaxing factor

Fig. 2. L-arginine role in the production of nitric oxide (NO) and selected properties of NO

In a randomized trial of patients with advanced cancer, it was observed that oral administration of arginine (14 g/day), glutamine ( $14 \mathrm{~g} /$ day) and $\beta$-hydroxy- $\beta$-methylbutyrate ( $3 \mathrm{~g} /$ day) for 24 weeks increased the lean body mass [16]. The improvement of this anthropometric parameter may suggest that arginine (glutamine and $\beta$-hydroxy- $\beta$-methylbutyrate) positively affects patient's nutritional status. But not only lean body mass is affected by immunonutrition. In the study of Braga et al., it was shown that pre-operative administration of preparations containing arginine and omega- 3 fatty acids improves body's immunity and reduces the incidence of infection [10]. Moreover, in a meta-analysis involving 6 studies, including 379 subjects undergoing surgery for head or neck cancer, it was observed that the supply of enteral nutrition combined with arginine at doses of 6.25-18.70 g/l reduced fistulae and shortened hospital stay [17]. Similarly, in the meta-analysis of Adiamah et al., summarizing 16 studies $(n=1387)$, it was observed that the administration of immunonutrition (omega-3 fatty acids, arginine, nucleotides) in the preoperative period in patients treated surgically for gastrointestinal cancer, reduced the rate of post-operative infectious complications and shortened hospital stay [18]. In addition, the Kanekiyo et al. study showed that the use of enteral immunotherapy (arginine, omega-3 fatty acids, nucleotides) in the preoperative period in patients with esophageal cancer, improves the parameters of nutritional status and reduces the incidence of infections [19].

Despite many potential benefits of using arginine described above, according to the ESPEN guidelines concerning clinical nutrition in surgery, there is no explicit recommendations regarding parenteral and enteral use of arginine in surgical patients [20]. Evidence is insufficient to suggest the supplementation of arginine alone [20]. Moreover, the interaction of dietary supplements enriched with arginine and functional properties of MDSCs (myeloidderived suppressor cells) is observed. MDSCs are produced in bone marrow under the influence of tumor cell derived substances [21]. MDSCs are heterogenous population of immune cells with immunosuppressive properties. They are classified as granulocytic (G)-MDSCs and 
monocytic (M)-MDSCs. It is noted that accumulation of these subpopulations is observed in malignancies, sepsis and severe trauma. They show negative effect on T lymphocytes function through arginine depletion and production of nitric oxide $[21,22]$. It should be mentioned that arginine depletion causes increased serine biosynthesis, glutamine anaplerosis, oxidative phosphorylation, decreased aerobic glycolysis and as a consequence effectively inhibits Warburg effect, which is described as the production of abundant amounts of lactate in the presence of sufficient oxygen [21]. The Warburg effect is the result of oxygen-induced extensive lactate production in both glycolysis as well as glutaminolysis pathways. It increases the production glucose-derived biomass required for unrestricted cells proliferation and tumor growth [23].

\section{Glutamine}

Glutamine is a conditionally essential amino acid, which plays a pivotal role in human body (Fig. 3). Because it is present in abundance in human body and it is not water-soluble, glutamine not always was considered a good candidate for immunonutrition. The participation of this amino acid in many processes however, changed the way it is viewed. Glutamine is an important element of ATP biosynthesis (adenosine triphosphate). As an element of glutathione (after the conversion into glutamic acid), it participates in the protection of the body cells against reactive oxygen species (ROS) [24]. Because it affects the intestinal mucosal integrity and the condition of GALT (gut associated lymphoid tissue), especially when it comes to the inhibition of proinflammatory cytokines production, it is considered a good supplementation for patients during post-surgical trauma [24, 25]. The term ,glutaminolysis" is one of the characteristic features of cancer cell metabolism. The transformations of glucose and glutamine in these cells are closely related [26].

Apart from the studies presented above, Chang et al. [28] evaluated the use of oral glutamine supplementation in patients with non-small cell lung cancer $(n=60)$. Glutamine in a dose of $10 \mathrm{~g} / 8 \mathrm{~h}$ received 30 patients. Administration of glutamine reduced the incidence of acute grade 2 and 3 esophagitis due to chemo-radiotherapy $(6.7 \%$ for glutamine-supplemented patients vs. $53.4 \%$ for non-sup- plemented cohort; $p=0.004)$. A decrease in weight reduction was also observed (20\% vs. $73.3 \%, p=0.01)$ [28].

Supporting nutritional therapy with glutamine improves the quality of life of patients with advanced gastric cancer. The Wang et al. study reported that in patients treated with chemotherapy, when given glutamine in the perioperative period, it protects the intestinal mucosa, as well as regulates the levels of MMP-2 (extracellular matrix metalloproteinase-2) and MMP-9 (extracellular matrix metalloproteinase-9) [29]. It should be emphasized that disturbances in the MMP/TIMP system (between matrix metalloproteinases and tissue metalloproteinase inhibitors), affect the development of many diseases, including cancer [30]. In another study, including patients with gastric cancer $(n=124)$ after gastrectomy, it was observed that the use of glutamine, in combination with arginine, omega-3 acids, nucleotides, improves the functioning of the immune system [31]. The proportion of $\mathrm{CD}^{+}$and $\mathrm{CD}^{+}$, as well as the ratio of $\mathrm{CD}^{+} / \mathrm{CD}^{+}, \mathrm{IgG}, \mathrm{IgM}, \operatorname{Ig}$ A were higher in the group receiving immunonutrition compared to those treated with the standard enteral formulation. In addition, the level of WBC, CRP and TNF- $\alpha$ was lower in the group of patients receiving immunosuppression. There was no statistically significant difference in the parameters of the nutritional status between both groups [31].

Glutamine is a specific nutrient that can be used in patients with HCT (hematopoietic cell transplantation). In the Ziegeler et al. study, it was observed that in patients after HCT, parenteral nutrition in combination with glutamine at a dose of $0.57 \mathrm{~g} / \mathrm{kg}$ body weight/day reduced infection frequency, improved nitrogen balance and shortened hospitalization [32]. According to the latest ESPEN's guidelines, there is no specific dose of glutamine recommended to be administered to patients with HCT. According to some studies, the correct dose is $0.6 \mathrm{~g} / \mathrm{kg}$ body weight/day [4]. In addition, glutamine should be given very carefully to patients with HCT with renal failure [4].

Summarizing the most recent ESPEN guidelines regarding surgical patients, there is no strong recommendations for the use of glutamine. Moreover, there is no convincing evidence to recommend the use of parenteral glutamine. Typically, the use of parenteral glutamine supplementation may be considered in patients who cannot be fed adequately enterally and as a consequence they require exclusive parenteral nutrition. In pancreatic surgery, the

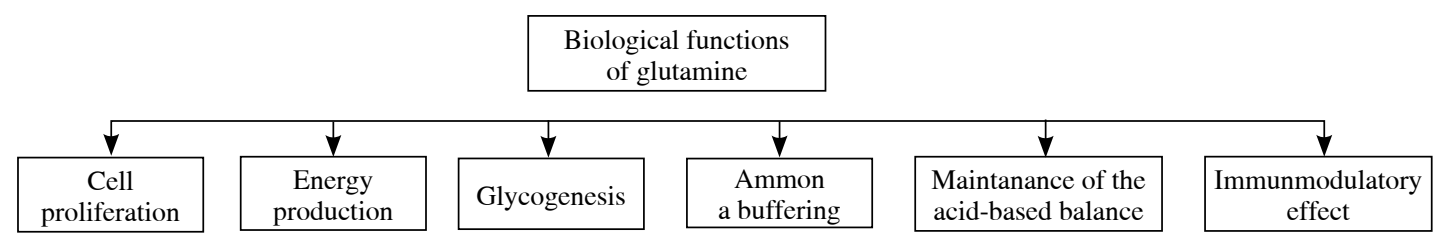

Fig. 3. The biological functions of glutamine. Own elaboration based on literature [27] 
effect of glutamine on oxidative stress and inflammatory response is negligible [20].

\section{Omega-3 fatty acids}

Eicosapentaenoic acid (EPA) is classified as omega-3 fatty acid. In the Kubota et al. study, it was noted that EPA inhibits the activity of NF- $\mathrm{NB}$ - one of the most important nuclear transcription factors contributing in inflammatory response - it activates pro-inflammatory cytokines production leading to e.g. immune system cells proliferation [33]. Apart from that, NF- $\kappa \mathrm{B}$ affects also proliferation, angiogenesis and formation of metastasis [33, 34] promoting tumor spreading. As a consequence of NF- $\kappa \mathrm{B}$ inhibition, EPA reduces also the production of IL- 6 and other pro-inflammatory cytokines, like IL-1 and TNF- $\alpha$. It induces also apoptosis of esophageal cancer cells TE-1 by activating an oxidative stress in these cells and thereby blocking NF- $\mathrm{kB}$-dependent escape from apoptosis [33]. Gene encoding COX-2 (cyclooxygenase-2) is also under the direct control of NF- $\kappa \mathrm{B}$, consequently EPA reduces the concentration of this enzyme [35]. It was also proved that EPA supplementation reduces the risk for esophageal adenocarcinoma in patients with Barrett's esophagus [36]. In general, it was proved that increased COX-2 expression is characteristic for inflammation and neoplastic changes [37].

Omega- 3 fatty acids are also used in patients after HCT. Oral supplementation of EPA at a dose of $1.8 \mathrm{~g} /$ day (3 weeks before transplantation up to 180 days after transplantation) in patients after HCT, reduces the symptoms of GvHD (graftversus-host disease) [38]. In another study, which was randomized and double-blinded, it has been shown that in patients after HCT, long-term supplementation with omega-3 acids (> 21 days) is particularly preferred. Supplementation with these acids modulates the immune system by reducing the concentration of inflammatory cytokines, such as IL-10 and TNF- $\alpha(p \leq 0.05)$ [39].

In a meta-analysis by Zhao et al. [40], including 16 randomized trials (1008 patients with gastrointestinal tumors) was reported that parenteral nutrition supplemented with omega-3 fatty acids (at a mean dose of 40.7-2000 mg/kg/day EPA $59.7-2250 \mathrm{mg} / \mathrm{kg} /$ day DHA), reduces inflammation and improves the functioning of the immune system. Levels of IL-6, TNF- $\alpha$, CRP were lower in patients receiving omega- 3 fatty acids compared to those in control groups. There was also a statistically significant difference in the incidence of postoperative infections between the study groups. Patients receiving omega- 3 fatty acids were less likely to have infections [40]. It was also shown that patients with oesophageal cancer after surgery, additionally treated with omega-3 fatty acids reduce the concentration of proinflammatory cytokines, such as IL-8 [41]. The concentration of 6-keto-PFG1 $\alpha$ (the product of spontaneous breakdown of prostacyclin $\mathrm{PGI}_{2}$ ), which reflects on decreased platelets activation, also decreased. The obtained results confirm not only the anti-inflammatory properties of omega-3 fatty acids, but also their effect on the reduction of platelet aggregation [41].

Immunonutrition with omega 3-fatty acids increased the concentration of omega- 3 fatty acids in plasma, however it did not affect overall HLA-DR expression in monocytes or clinical outcome following oesophagogastric cancer surgery [20]. In prospective, randomized, double-blind and placebo-controlled trial, it was shown that oral supplementation with omega-3 fatty acids exerts anti-inflammatory effects in surgical patients with colorectal cancer [42]. Notwithstanding, the risk of postoperative complications was not reduced. Omega-3 fatty acids were incorporated into granulocytes in patients receiving omega-3 fatty acids but it was not associated with improved postoperative clinical outcome [42].

Omega 3-fatty acids (EPA and DHA) supplementation was also assessed in patients with newly diagnosed breast cancer [43]. The patients received $2 \mathrm{~g} /$ day of fish oil for 30 days, which contain $1.8 \mathrm{~g}$ of omega- 3 fatty acids. Supplementation maintained the level of CD4+ T cells and serum levels of hsCRP (high sensitivity C-reactive protein). These results confirm beneficial effects of using EPA and DHA on the immune system and less active inflammatory response in this group of patients [43].

\section{Nucleotide acids}

Nucleotides may exist in free and bound form (nucleic acids of RNA and DNA) being synthesized in thehuman body. In order to cover the total demand for nucleotides, it is essential to provide them along with the diet [2]. The deficiency of nucleotides occurs, among others, in diseases with increased catabolism. Nucleotides used as immunomodulatory components for patients diagnosed with cancer, are present mainly in mixtures with other substances (usually arginine, glutamine, omega-3 fatty acids). They affect the maturation, activation and proliferation of lymphocytes [3]. Furthermore, supplementation with nucleotides supports the regeneration of intestinal villi [2].

Preoperative immunonutrition reduces complication rates after salvage surgery in head and neck cancer, which was shown in the most recent Mueller et al. trial [44]. This study included 96 patients (intervention group: 51, control group: 45). The intervention group received ( 3 units per day for 5 days before surgery) omega-3 fatty acid ( $1 \mathrm{~g} /$ unit), arginine (3.8 g/unit), RNA-nucleotides (0.39 g/unit) and soluble guar fiber ( $3 \mathrm{~g} / \mathrm{unit}$ ). The use of preoperative immunonutrition significantly reduced the length of hospital stay (6 days vs. $17, p<0.001$ ) and overall complications (35\% vs. 58\%). The differences in mortality and hospital readmission weren't found [44].

\section{Prebiotics and probiotics}

According to the definition proposed by WHO (World Health Organization), probiotics are living microorganisms 
which given in the right dose have a beneficial health effect on the host's organism [45]. The composition of the gastrointestinal microbiome is closely related to the efficacy and safety of anticancer treatment. Microbiome includes not only bacteria, but also viruses, fungi and archaea. Its' composition depends on many factors, including type of food intake, used treatment, and taken probiotics [45]. It is worth emphasizing that among the causes of dysbiosis (an imbalance in the normal gut microbiota composition), pharmacological treatment is often mentioned in patients with cancer. One of the methods of interference in intestinal microbiome is the administration of probiotic strains. In the study of Gerbitz et al. [46], on an animal model, the administration of the Lactobacillus rhamnosus GG probiotic reduced bacterial translocation and the incidence of GvHD disease, as well as improved survival after HCT. In another study [47], already in patients undergoing HCT, it was observed that the administration of the same probiotic strain reduced the incidence of GvHD grade 3 and 4, but did not reduce the overall incidence of this disease. In patients with tumors of the gastrointestinal tract treated with surgery, probiotics reduce the incidence of diarrhea.

Probiotics as immunomodulatory components influence the immune system by decreasing the concentration of proinflammatory cytokines (IL-8, TNF- $\alpha$ ), which was demonstrated in postoperatively, enterally fed patients with gastric cancer [48]. Furthermore, probiotic strain Lactobacillus plantarum $299 \mathrm{v}$ can strengthen the immune protection against viral and bacterial infections. Rask et al. study reported that the administration of this probiotic increased the expression of activation markers on $\mathrm{CD}^{+}$ $\mathrm{T}$ cells and memory cell marker (CD45RO) on $\mathrm{CD}^{+}$ T lymphocytes [49].

Probiotic strains may inhibit the process of carcinogenesis [50]. In an animal model study, it was observed that the administration of Lactobacillus bacteria reduced the incidence of cancer, regulated the expression of Tolllike receptors, such as TRL-2, TRL-4 and TRL-9 [50]. The stimulation of TLRs is a signal that activates mechanisms of non-specific immunity. TLRs also affect the function of Treg ( $\mathrm{T}$ regulatory) $\mathrm{CD} 4{ }^{+} \mathrm{CD} 25^{+}$cells leading to their induction and as the consequence to the suppression of the immune response [51].

Nutritional treatment, which is one of the most important part of anti-cancer therapy, is associated with the occurrence of side effects, such as vomiting, flatulence, stomach pain and diarrhea. Probiotics have the ability to reduce the incidence of diarrhea in patients with gastric cancer who received enteral nutrition after surgery [48, 52].

In addition to probiotics, also prebiotics have the ability to modify the intestinal microbiome. They are defined as non-digestible nutrients that favorably affect the human body by selectively stimulating the growth and activity of bacteria living in the large intestine [53]. They are used for the production of short-chain fatty acids (SCFAs), which when produced in the right amount, favorably affect the maintenance of the intestinal barrier. Butyric acid, which belongs to the SCFA group, has anti-inflammatory properties and stimulates the process of reconstruction of the intestinal epithelium [53].

\section{Conclusions}

Immunonutrition (arginine, glutamine, omega-3 fatty acids, nucleotide acids, pre- and probiotics) is a modern method of complementary treatment of cancer. It has a positive effect on the functioning of the immune system, including the ability to react against pathogens, reduce the concentration of pro-inflammatory cytokines and maintain the balance of CD4/CD8 lymphocytes. The knowledge about immunonutrition is still limited. It seems reasonable to suggest standard ONS as a preoperative choice due to higher cost and limited retail availability of immunonutrition. Moreover, there is information available about negative effect of using these immunomodulatory components (such as glutamine in breast cancer). Clinical trials usually assess mixture of few substances and that is why it is hard to determine what is the role of immunonutrient alone. In addition, the optimal components of immunonutrients have yet to be adequately determined and may vary for patients based on the proposed procedures. Further studies should assess the effectiveness, as well as safety of immunonutrition usage in patients with cancer. There is a need for properly design randomized and placebo-controlled trials that stratify patients appropriately and determine the optimal composition and duration of therapy regarding isocaloric and isonitrogenous formulas.

\section{The authors declare no conflict of interest}

\section{References}

1. Kłęk S, Jankowski M, Kruszewski W, et al. (2015): Standardy leczenia żywieniowego. Nowotwory. Journal of Oncology 4: 320-337.

2. Szefel J, Kruszewski W, Ciesielski M (2009): Żywienie immunomodulujące w onkologii. Współcz Onkol 1: 9-15.

3. Prieto I, Montemuino S, Luna J, et al. (2017): The role of immunonutritional support in cancer patients: current evidence. Clin Nutr 6: 1457-1464.

4. Arends J, Bachmann P, Baracos V, et al. (2017): ESPEN guidelines on nutrition in cancer patients. Clin Nutr 1: 11-48.

5. Potemski P, Krzakowski M, Duchnowska R, et al. (2013): Zalecenia postępowania diagnostyczno-terapeutycznego $\mathrm{w}$ nowotworach złośliwych. Via Medica, Gdańsk; 616.

6. Graboń W. (2006): Arginina- podstawowy aminokwas w procesie nowotworzenia. Postep Hig Med Dosw 60: 483-489.

7. Ścibior D, Czeczot H (2004): Arginina - metabolizm i funkcje w organizmie człowieka. Postep Hig Med Dosw 58: 321332. 
8. Stępnik M (2001): Molekularne aspekty toksycznego działania tlenku azotu. Medycyna Pracy 52: 375-381.

9. Lee M, Rey K, Besler K, et al. (2017): Immunobiology of Nitric Oxide and Regulation of Inducible Nitric Oxide Synthase. In: Kloc M. (eds.). Macrophages. Results and Problems in Cell Differentiation. Vol. 62. Springer, Cham.

10. Braga M, Gianotti L, Vignali A, Carlo V (2002): Preoperactive oral arginine and n-3 fatty acid supplementation improves the immunometabolic host response and outcome after colorectal resection for cancer. Surgery 132: 805-814.

11. Wheatley DN, Scott L, Lamb J, Smith S (2000): Single Amino Acid (Arginine) Restriction: Growth and Death of Cultured HeLa and Human Diploid Fibroblasts. Cell Physiol Biochem 10: 37-55.

12. Barbul A, Lazarou SA, Efron DT, et al. (1990): Arginine enhances wound healing and lymphocyte immune responses in humans. Surgery 108: 331 .

13. Evoy D, Lieberman MD, Fahey TJ 3rd, Daly JM (1998): Immunonutrition: the role of arginine. Nutrition 14: 611-617.

14. Rosenthal MD, Carrott PW, Patel J, et al. (2016): Parenteral or enteral arginine supplementation safety and efficacy. J Nutr 12: 2594-2600.

15. Gundogdu RH, Temel H, Bozkirli BO, et al. (2017): Mixture of arginine, glutamine and $\beta$-hydroxy- $\beta$-methylbutyrateenhances the healing of ischemicwounds in rats. J Parenter Enteral Nutr 6: 1045-1050.

16. May PE, Barber A, D'Olimpio JT, et al. (2002): Reversal of cancer-related wasting using oral supplementation with a combination of beta-hydroxy-beta-methylbutyrate, arginine and glutamine. Am J Surg 183: 471-479.

17. Vidal-Casariego A, Calleja-Fernandez A, Villar-Taibo R, et al. (2014): Efficacy of arginine-enriched enteral formulas in the reduction of surgical complications in head and neck cencer: a systematic review and meta-analysis. Clin Nutr Edinb Scotl 6: 951-957.

18. Adaimah A, Skorepa P, Weimann A, Lobo DN (2019): The impact of preoperative immune modulating nutrition on outcomes in patients undergoing surgery for gastrointestinal cancer: a systematic review and meta-analysis. Ann Surg 270: 247-256.

19. Kanekiyo S, Takeda S, Lida M, et al. (2019): Efficacy of perioperative immunonutrition in esophageal cancer patients udergoing esophagectomy. Nutrition 59: 96-102.

20. Weimann A, Braga M, Carli F, et al. (2017): ESPEN guideline: clinical nutrition in surgery. Clin Nutr 36: 623-650.

21. Łuczyński W, Krawczuk-Rybak M, Stasiak-Barmuta A (2008): Komórki supresyjne pochodzące z linii mieloidalnej - nowy mechanizm upośledzenia odporności w chorobach nowotworowych. Post Hig Med Dosw 62: 18-22.

22. Sendo S, Saegusa J, Morinobu A (2018): Myeloid-derived suppressor cells in non-neoplastic inflamed organs. BMC Cancer 38: 19.

23. Graboń W, Otto-Ślusarczyk D, Barańczyk-Kuźma A (2018): Wpływ tlenu na efekt Warburga: czy w komórkach nowotworowych mleczan powstaje tylko z glukozy? Post Hig Med Dosw 72: 481-490.

24. Kim H (2011): Glutamine as an immunonutrient. Yonsei Med J 6: 892-897.

25. O'Riordain MG, De Beaux A, Fearon KC (1996): Effect of glutamine on immune function in the surgical patient. Nutrition 12: 82-84.
26. Malenda A, Nowis AD (2013): Znaczenie metabolizmu glukozy w diagnostyce oraz terapii nowotworów układu krwiotwórczego i chłonnego. Hematologia 3: 227-238.

27. Coqueiro AY, Rogero MM, Tirapegui J (2019): Glutamine as an anti-fatigue amino acid in sports nutrition. Nutrients 11: 863 .

28. Chang SC, Lai YC, Hung JC, Chang CY (2019): Oral glutamine supplements reduce concurrent chemoradiotherapy-induced espophagitis in patients with advanced non-small cell lung cancer. Medicine 8: e14463.

29. Wang J, Li Y, Qi Y (2017): Effect of glutamine-enriched nutritional support on intestinal mucosa barrier function, MMP-2, MMP-9 and immune function in patients with advanced gastric cancer during perioperative chemotherapy. Oncol Lett 3: 3606-3610.

30. Trojanek J (2012): Metaloproteinazy macierzy zewnątrzkomórkowej i ich tkankowe inhibitory. Postępy Biochemii 3: 353-362.

31. Li K, Xu Y, Hu Y, et al. (2019): Effect of enteral immunonutrition on immune, inflammatory markers and nutitional status in gastric patients undergoing gastrectomy: a randomized, double-blind controlled trial. J Invest Surg 19: 1-10.

32. Ziegler TR, Young LS, Benfell K, et al. (1992): Clinical and metabolic efficacy of glutamine-supplementedparenteral nutrition after bone marrow transplantation. A randomized, double-blind, controlled study. Ann Intern Med 10: 821-828.

33. Kubota H, Matsumoto H, Higashida M, et al. (2013): Eicosapentaenoic acid modifies cytokine activity and inhibits cell proliferation in an oesophageal cancer cell line. Anticancer Res 10: 4319-4324.

34. Aggarwal BB, Sung B (2011): NF- $\kappa B$ in cancer: a matter of life and death. Cancer Discov 6: 469-471.

35. Lee SA, Kim HJ, Chang KC, et al. (2009): DHA and EPA Down-regulate COX-2 Expression through Suppression of NF-kappaB Activity in LPS-treated Human Umbilical Vein Endothelial Cells. Korean J Physiol Pharmacol 4: 301-307.

36. Mehta SP, Boddy AP, Cook J, et al. (2008): Effect of n-3 polyunsaturated fatty acids on Barrett's epithelium in the human lower esophagus. Am J Clin Nutr 4: 949-956.

37. Burdan F, Chałas A, Szumiło J (2006): Cyklooksygenaza i prostanoidy- znaczenie biologiczne. Post Hig Med Dosw 60: 129-141.

38. Takatsuka H, Takemoto Y, Iwata N, et al. (2001): Oral eicosapentaenoic acid for complications of bone marrow transplantation. Bone Marrow Transplant 8: 769-774.

39. Baena-Gómez MA, de la Torre-Aguilar MJ, AguileraGarcía CM, Olza J, Pérez-Navero JL, Gil-Campos M (2016): Inflammatory response using different lipid parenteral nutrition formulas in children after hematopoietic stem cell transplantation. Nutr Cancer 5: 804-810.

40. Zhao Y, Wang C (2018): Effect of omega-3 polyunsaturated fatty acid-supplemented parenteral nutrition on inflammatory and immune function in postoperative patients with gastrointestinal malignancy: A meta-analysis of randomized control trials in China. Medicine 16: e0472.

41. Aiko S, Yoshizumi Y, Tsuwano S, et al. (2005): The effects of immediate enteral feeding with a formula containing high levels of omega-3 fatty acids in patients after surgery for esophageal cancer. J Parenter Enter Nutr 3: 141-147.

42. Sorensen LS, Thorlacius-Ussing O, Rasmussen HH, et al. (2014): Effects of perioperative supplementation with omega-3 fatty acids on leukotriene B4 and leukotriene B5 production by stimulated neutrophils in patients with colorectal 
cancer: a randomized, placebo-controlled intervention trial. Nutrients 10: 4043-4057.

43. Paixao EMDS, Oliveira ACM, Pizato N, et al. (2017): The effects of EPA and DHA enriched fish oil on nutritional and immunological markers of treatment naive breast cancer patients: a randomized double-blind controlled trial. Nutr J 1: 71.

44. Mueller SA, Mayer C, Bojaxhiu B, et al. (2019): Effect of preoperative immunonutrition on complications after salvage surgery in head and neck cancer. J Otolaryngol Head Neck Surg 1: 25.

45. Mojka K (2014): Probiotyki, prebiotyki, synbiotyki - charakterystyka i funkcje. Problem Hig Epidem 3: 541-549.

46. Gerbitz A, Schultz M, Wilke A, et al. (2004): Probiotic effects on experimental graft-versus-hostdisease: let them eat yogurt. Blood 11: 4365-4367.

47. Gorshein E, Wei C, Ambrosy S, et al. (2017): Lactobacillus rhamnosus GG probiotic enteric regimen does not appreciably alter the gut microbiome or provide protection against GVHD after allogeneic hematopoietic stem cell transplantation. Clin Transplant 31. doi: 10.1111/ctr.12947.

48. Xie H, Lu Q, Wang H, et al. (2018): Effects of probiotics combined with enteral nutrition on immune function and inflammatory response in postoperative patients with gastric cancer. J Buon 23: 678-683.

49. Rask C, Alderberth I, Berggren A, et al. (2013): Differential effect on cell-mediated immunity in human volunteers after intake of different lactobacilli. Clin Exp Immunol 2: 321-332.

50. Kuugbee ED, Shang X, Gamallat Y, et al. (2016): Structural change in microbiota by a probiotic cocktail enhances the gut barrier and reduces cancer via TRL2 in a rat model of colon cancer. Dis Dig Sci 61: 2908-2920.

51. Majewska M, Szczepanik M (2006): Rola receptorów tollpodobnych (TRL) w odporności wrodzonej i nabytej oraz ich funkcja w regulacji odpowiedzi immunologicznej. Postep Hig Med Dos 60: 52-63.

52. Zhao R, Wang Y, Huang Y, et al. (2017): Effects of fiber and probiotics on diarrhea associated with enteral nutrition in gastric cancer patients. Medcinie 96: e8418.

53. Kaźmierczak-Siedlecka K, Piekarska A, LubienieckaArchutowska E, et al. (2019): Stan odżywienia chorych po transplantacji komórek krwiotwórczych. Acta Haematologica Polonica 1: 1-9. 